\title{
Comparative palynological analysis of Lygodium venustum Sw. and L. volubile Sw. (Lygodiaceae)
}

\author{
JUAN P. RAMOS GIACOSA ${ }^{1,3}$, MARTA A. MORBELLI ${ }^{1,3}$ and GABRIELA E. GIUDICE ${ }^{2}$ \\ ${ }^{1}$ Cátedra de Palinología, Facultad de Ciencias Naturales y Museo, Universidad Nacional de La Plata, \\ Paseo del Bosque, s/nº, B1900FWA, La Plata, Argentina \\ ${ }^{2}$ Cátedra de Morfología Vegetal, Facultad de Ciencias Naturales y Museo, \\ Universidad Nacional de La Plata, Paseo del Bosque, s/nº, B1900FWA, La Plata, Argentina \\ ${ }^{3}$ Consejo Nacional de Investigaciones Científicas y Técnicas (CONICET), \\ Av. Rivadavia, 1917, C1033AAJ, Buenos Aires, Argentina
}

Manuscript received on August 28, 2012; accepted for publication on December 6, 2012

\begin{abstract}
The genus Lygodium Sw. is one of the few climbing ferns in the world. The spores of L. venustum Sw. and $L$. volubile Sw. were studied using light, scanning, and transmission electron microscopy. This work is based on herbarium material. The spores are trilete, triangular, with straight to convex sides in polar view. The equatorial diameter is $72-104 \mu \mathrm{m}$, and the polar diameter is $64-84 \mu \mathrm{m}$. The ornamentation in $L$. venustum is verrucate-tuberculate while in L. volubile, it is verrucate-tuberculate in the proximal face but with a few ridges on the distal face, where a micro-ornamentation constituted by verrrucae and tubercles is observed. An equatorial ridge is also present. The exospore is two-layered; in L. venustum, it is smooth in contrast with the ornamented exospore of $L$. volubile. The perispore of the two species analyzed is similar. This wall is four-layered with particular elements arranged radially in the middle layer. On the spores surface of both species, few spheroids are observed. The results introduced in the current study may be useful for the systematics of the genus as well as for phylogenetic purposes.
\end{abstract}

Key words: Lygodiaceae, Lygodium, morphology, spores, ultrastructure.

\section{INTRODUCTION}

The genus Lygodium Sw. is one of the few climbing ferns in the world, presenting leaves of more than 10 meters long. Climbing leaves that reach considerable heights are unusual in ferns and are best developed in Lygodium and in Salpichlaena volubilis (Kaulf.) J. Sm. (Blechnaceae). Lygodium is distinct by its twining fronds and monangial, indusiate sori. The genus is part of the family Lygodiaceae and approximately 25 species were reported in the

Correspondence to: Juan Pablo Ramos Giacosa

E-mail:.jpramosgiacosa@hotmail.com
Old and New World (Tryon and Tryon 1982, Mickel and Smith 2004, Smith et al. 2006).

In the American tropics, between six to eight species were quoted while in the eastern United States, only two species were reported (Tryon and Tryon 1982). One of them, Lygodium microphyllum (Cav.) R. Br. was introduced in the United States and aggressively invaded forest-dominated wetlands in southern and central Florida (Madeira et al. 2008).

Lygodium venustum $\mathrm{Sw}$. is distributed from Mexico to Paraguay and L. volubile Sw. grows from Mexico to Argentina (Mickel and Smith 2004). 
To date, only a few studies on the spores of the American species of Lygodium were carried out. The spores of $L$. cubense Kunth, L. heterodoxum Kunze, L. reticulatum Schkuhr, $L$. venustum and $L$. volubile were illustrated with a scanning electron microscope (SEM) by Tryon and Tryon (1982).

De la Sota and Morbelli (1987) showed with SEM the spores of $L$. volubile from Argentina.

In a comparative study of fossil and extant spores of Schizaeacea, Van Konijnenburg-van Cittert (1991) recognized evolutionary trends in the different genera of the family and illustrated with SEM the spores of L. japonicum and L. volubile.

The spores of several species of the genus from the Old and New World were analyzed by Tryon and Lugardon (1991) using a SEM. Additionally, they illustrated with transmission electron microscope (TEM) the spores of L. japonicum and L. heterodoxum from Guatemala, and L. volubile from British Guiana.

Lugardon (1974) observed the spores of $L$. japonicum from a cultivated plant in Kew using a TEM.

The aim of this work is to analyze the spore morphology and wall ultrastructure of Lygodium venustum and L. volubile with LM, SEM and TEM in order to contribute to the knowledge concerning the spores of the genus, and to give new characters for systematic or phylogenetic purposes.

\section{MATERIALS AND METHODS}

Spores were obtained from herbarium specimens from the following institutions: Instituto de Botánica del Nordeste (CTES), División Plantas Vasculares, Facultad de Ciencias Naturales y Museo, Universidad Nacional de La Plata (LP) and Instituto de Botánica Darwinion (SI).

The spores were studied using light (LM), scanning (SEM) and transmission (TEM) electron microscopy. For LM, the spores were treated with hot 3\% sodium carbonate for two minutes in order to preserve the perispore (Morbelli 1980) and acetolyzed according to the method of Erdtman (1960).
For SEM, the material was treated with hot $3 \%$ sodium carbonate, washed, dehydrated, suspended in $96 \%$ ethanol and then transferred to acetate plates. After drying, they were coated with gold.

For studies with TEM, dry material from herbarium specimens was hydrated following the technique by Rowley and Nilsson (1972), using phosphate buffer and alcian blue (AB). Then, the material was fixed with Glutaraldehyde $+1 \%$ Alcian Blue in phosphate buffer for $12 \mathrm{~h}$ and postfixed with $1 \% \mathrm{OsO}_{4}$ in water plus $1 \%$ Alcian Blue. The spores were dehydrated in an acetone series and then embedded in Spurr soft mixture. Three $\mu \mathrm{m}$ thick sections were stained with toluidine blue and observed with LM. Ultrathin sections were stained with $1 \%$ uranyl acetate for $15 \mathrm{~min}$ followed by lead citrate for three min.

The observations were made with an Olympus BH2, a JEOL JSMT-100 scanning electron microscope, and a Zeiss T-109 transmission electron microscope.

STUDied MATERiaL

Lygodium venustum: Brasil, Estado Mato Grosso, 4-V-1973, Anderson 9721 (LP); 7 km from Bela Vista, 26-VI-1977, Krapovickas y Schinini 32.685 (LP). Bolivia: Dpto. Beni, Prov. Ballivian, 8-XI1985, Solomon 14.626 (LP); Loma de Palmasola, IX-1977, Rolleri 19 (LP).

Lygodium volubile: Argentina, Prov. Misiones, Dpto. Iguazú, Camino a Pto. Canoas, 6-V-1981, Zuloaga et al. 2161 (SI), Dpto. El dorado, Santuario Virgen de Paticuá, 26-I-2008, Keller \& Franco 4928 (CTES); Dpto. Gral. San Martín, Puerto Rico, X-1977, Cabrera 28802 (LP). Brasil, Estado Minas Gerais, Estación experimental Pacheco, 29-V-1944, Hemiger 1273 (LP); 10 km from Cayambú, 11-VI1957, Pabst 4087 (LP); Estado de Rio de Janeiro, Pr. Passa Tres, 19-IX-1964, Trinta 857 (LP); Estado Rondônia, Basin of Rio Madeira, Rio Bananeiras, 5-VIII-1968, Prance et al. 6.787 (LP). 


\section{RESULTS}

\section{LYGODIUM VENUSTUM (Figs. 1, 3 A-B, 4)}

The spores are trilete, triangular, with straight sides in polar view. In equatorial view, the proximal face is convex and the distal face is hemispheric. The equatorial diameter is $72-104 \mu \mathrm{m}$, and the polar diameter is $68-84 \mu \mathrm{m}$. The laesurae are $32-$ $52 \mu \mathrm{m}$ long.

Observed by SEM (Fig. 1) the spores are verrucate-tuberculate with abundant perforations of variable sizes. The verrucae and tubercles are in some cases fused, forming short ridges (Fig. 1 D). The laesurae have the same ornamentation as the spore surface. On the spore surface, few spheroids are observed particularly, on the distal face.

When analyzed with TEM (Fig. 4), the exospore is $4.2-5.9 \mu \mathrm{m}$ thick and two-layered: having an inner layer of 0.1-0.5 $\mu \mathrm{m}$ thick and an outer layer of 4.1-5.4 $\mu \mathrm{m}$ thick.

The perispore is $1.2-2 \mu \mathrm{m}$ thick and fourlayered. The inner layer, P1, is 0.13-0.16 $\mu \mathrm{m}$ thick,
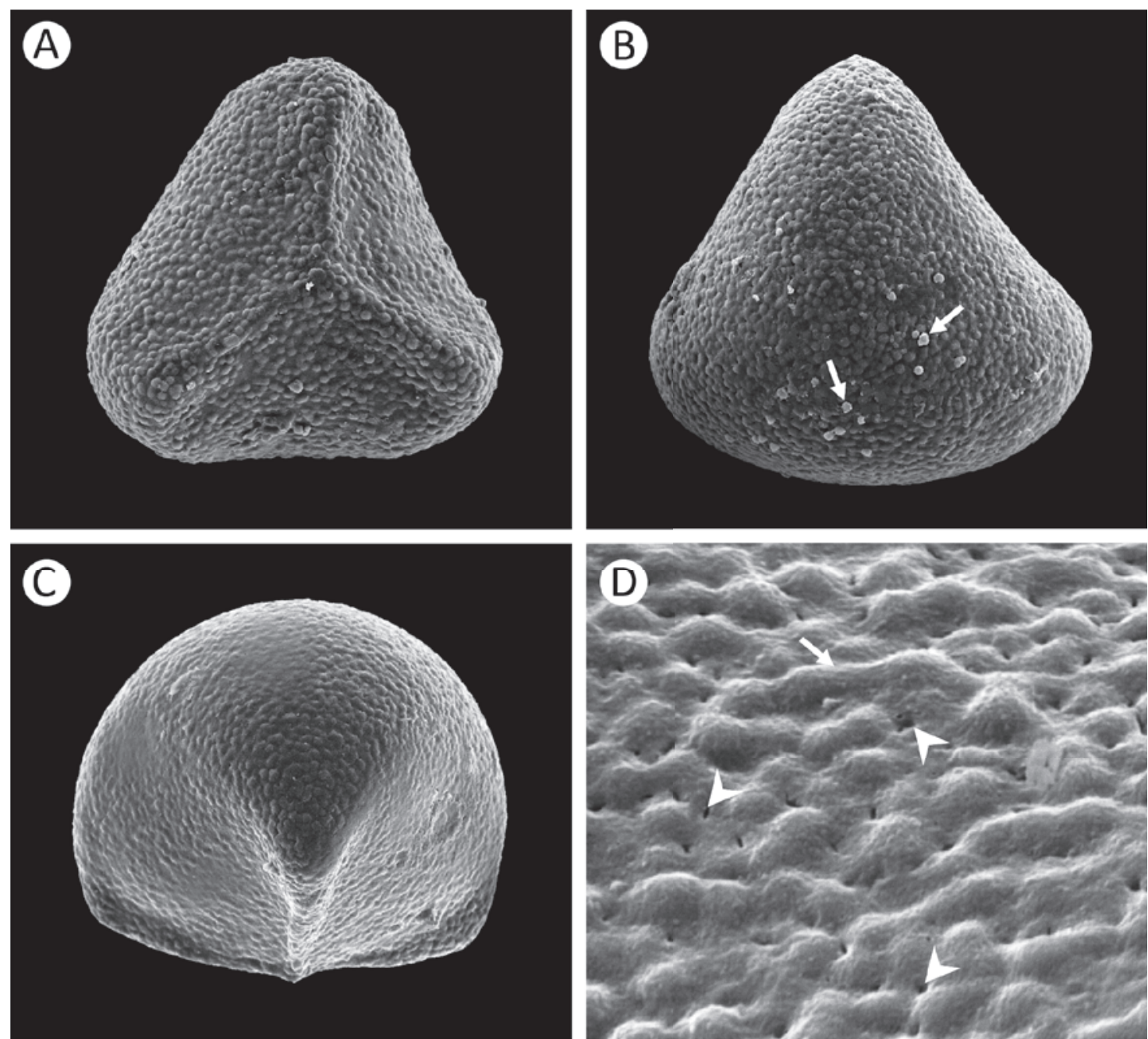

Fig. 1 - Spores of Lygodium venustum with SEM.

A. Proximal view of a triangular spore with straight sides. B. Distal view of a spore. The ornamentation is verrucatetuberculate with a few spheroids observed on the spore surface (arrows). C. Equatorial view of a spore. D. Detail of the spore surface ornamented by verrucae and tubercles. In some cases they are fused forming short ridges (arrow). Abundant perforations are seen on the perispore surface (arrowheads). Scale bars: A-C: $20 \mu \mathrm{m}, \mathbf{D}: 5 \mu \mathrm{m}$. 

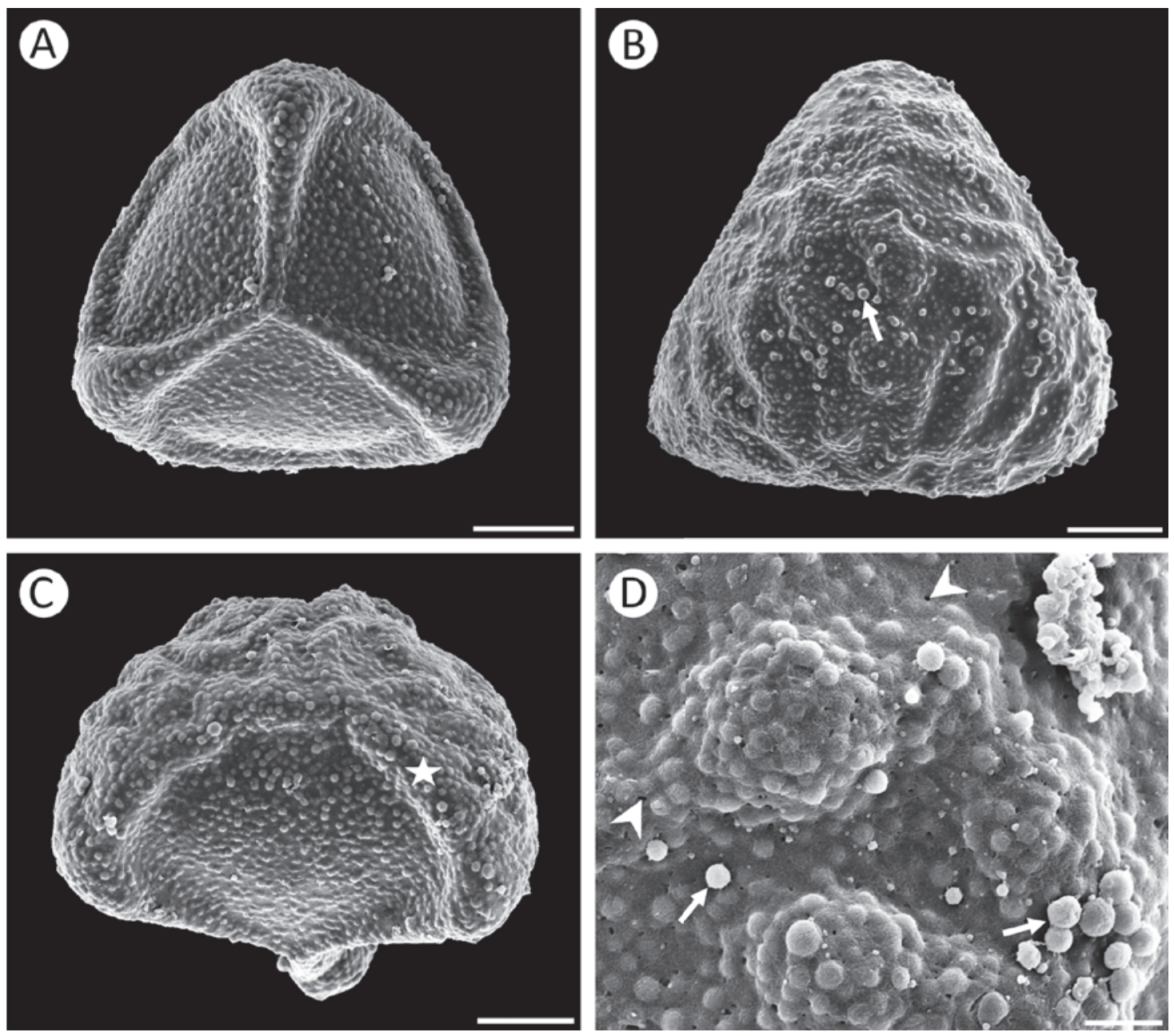

Fig. 2 - Spores of Lygodium volubile with SEM.

A. Proximal view of a triangular spore with straight to convex sides. The ornamentation is verrucate-tuberculate. B. Distal view of a spore. The ornamentation is composed of a few single or fused ridges with a micro-ornamentation of verrucae and tubercles. Spheroids are observed on the spore surface (arrow). C. Equatorial view of a spore. An equatorial ridge (star) delimits facets proximally. D. Detail of the distal ornamentation. Some single or fused spheroids (arrows) are observed on the verrucae and tubercles of the perispore. Abundant perforations are also visible on the spore surface (arrowheads). Scale bars: A-C: $20 \mu \mathrm{m}, \mathbf{D}: 5 \mu \mathrm{m}$.

smooth and with two strata: the inner stratum is strongly adhered to the exospore and more contrasted than the outer one. Layer P2 0.6-0.7 $\mu$ m thick, is constituted by radially arranged elements. In this layer, contrasted areas alternate with lesser contrasted ones. Layer P3 is $0.5-1.3 \mu \mathrm{m}$ thick and more contrasted than P1 and P2 layers. The outer layer, $\mathrm{P} 4$, is $60-75 \mathrm{~nm}$ thick, with two strata, the outer being more contrasted than the inner stratum. This layer covers the outer surface of P3 layer.
The variations in thickness of P3 layer form the elements of the spore ornamentation constituted by verrucae and tubercles. The few spheroids found in the distal face of the SEM images (Fig. 1 B) can be observed sectioned (Fig. 4 D) on the spore surface. They are similar in structure and contrast to layer P3.

LYGODIUM VOLUBILE (Figs. 2, 3 C-D, 5)

The spores are trilete, triangular, with straight to convex sides in polar view. In equatorial view, the 

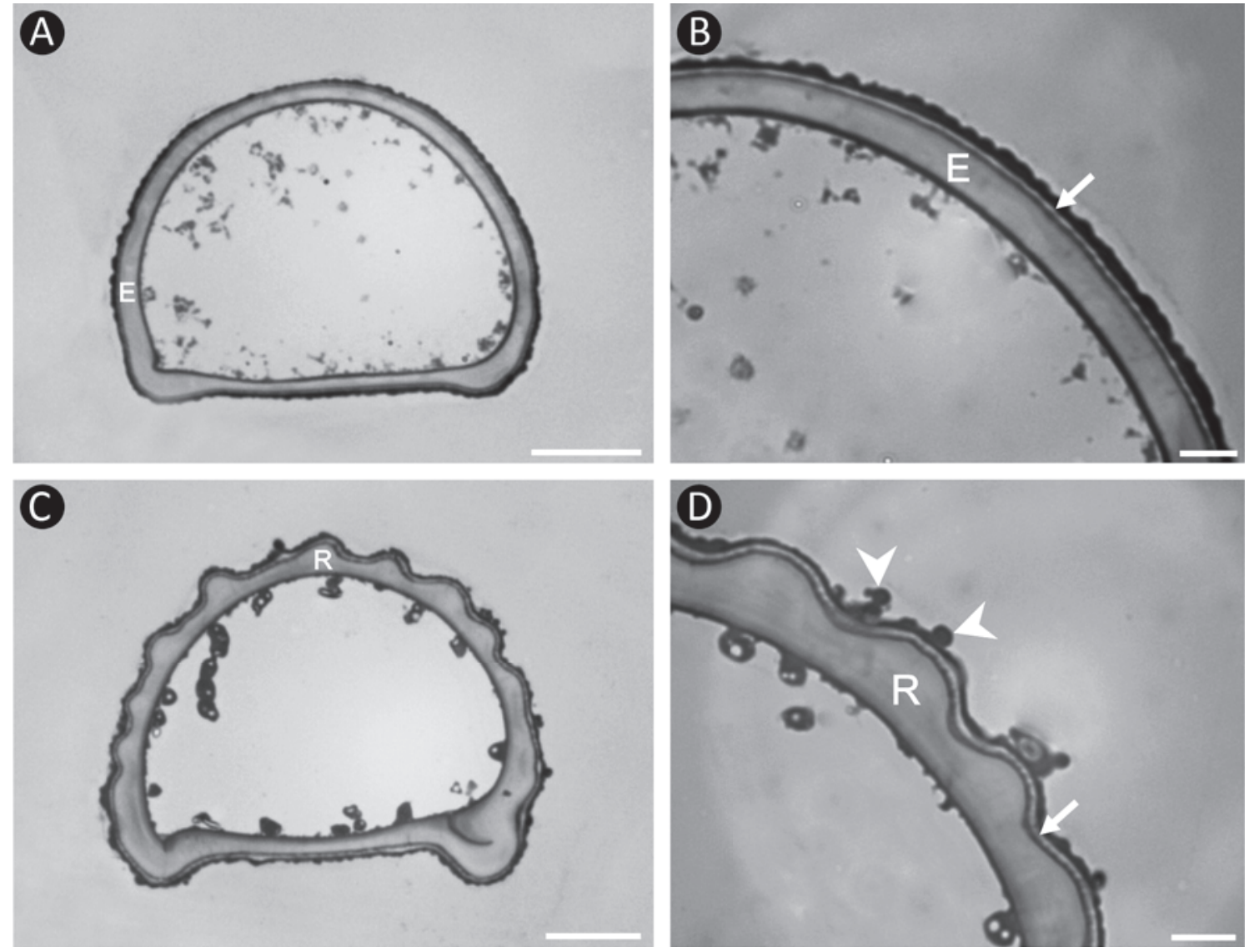

Fig. 3 - Sections of spores of Lygodium venustum and L. volubile with LM.

A-B. Lygodium venustum. A smooth exospore (E) is evident in proximal and distal faces of the spore. Above the exospore the perispore (arrow) is observed. C-D. Lygodium volubile. The exospore of the distal face has a wavy margin that correspond to the ridges (R) seen on the surface. Above the exospore the perispore (arrow) is evident. Some spheroids are seen on the perispore surface (arrowheads). Scale bars: A, C: $20 \mu \mathrm{m}, \mathbf{B}, \mathbf{D}: 5 \mu \mathrm{m}$.

proximal face is convex and the distal face is hemispheric. The equatorial diameter is $80-104 \mu \mathrm{m}$, and the polar diameter is $64-80 \mu \mathrm{m}$. The laesurae are $36-48 \mu \mathrm{m}$ long.

Observed by SEM (Fig. 2) the spores are verrucate-tuberculate on the proximal face. Single or fused ridges are seen on the distal face. On ridge surfaces, the micro-ornamentation is verrucate-tuberculate, similar to that observed on the proximal face. An equatorial ridge is present and it delimits facets proximally. The laesurae are also ornamented with verrucae and tubercles. Abundant perforations of variable sizes are also present on the perispore surface.
On the spore surface, few spheroids are observed. They are single or fused to one another and are more abundant on the distal face.

Analyzed with TEM (Fig. 5), the exospore is 1.8-5.2 $\mu \mathrm{m}$ thick and two-layered: having an inner layer $0.2-0.3 \mu \mathrm{m}$ thick, more contrasted than the outer one, and an outer layer 1.6-5 $\mu \mathrm{m}$ thick. The outer exospore layer is smooth in the proximal face with a wavy margin in the distal face.

Radial channels with dark contents are observed in the outer layer of the exospore, particularly at both sides of the laesurae area (Fig. 5 A-B).

The perispore is $0.5-1.6 \mu \mathrm{m}$ thick, and fourlayered. The inner layer, P1, is $0.04-0.1 \mu \mathrm{m}$ thick, 

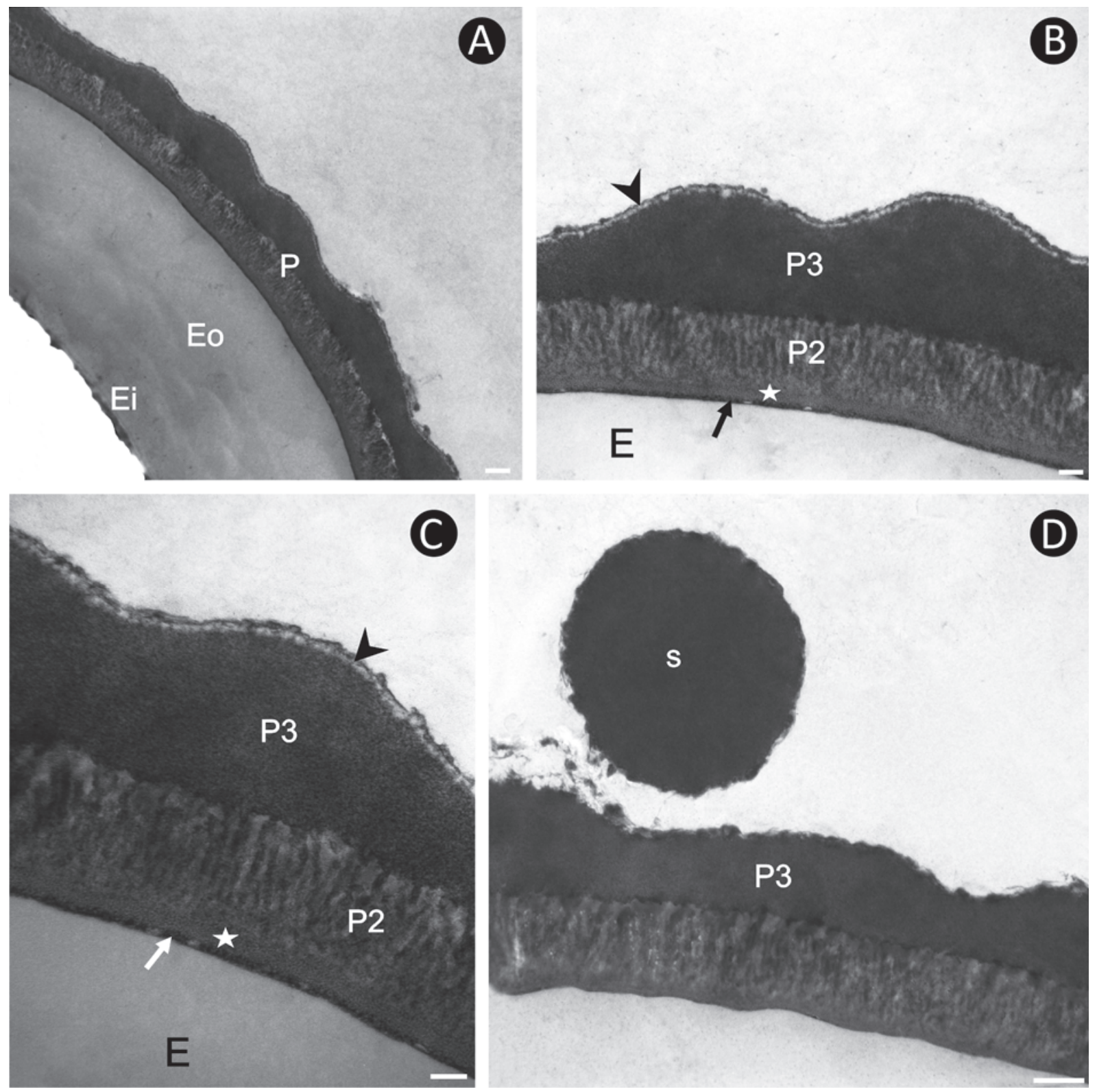

Fig. 4 - Spores of Lygodium venustum with TEM.

A. Section through the sporoderm. The exospore is two-layered: an inner layer (Ei) and an outer layer (Eo), the latter is less contrasted and thicker. On the exospore, the perispore $(\mathrm{P})$ is evident. B-C. The perispore is four-layered. The inner layer has two strata (arrow and star) which are smooth and strongly adhered to the exospore. The P2 layer is constituted of radially arranged elements. The P3 layer forms the elements of the ornamentation. The outer layer, P4 (arrowhead), covers the outer surface of the P3 layer. Below, the exospore (E) is observed. D. An Spheroid (s) with a similar structure and contrast to P3 layer is observed. Scale bars: A, D: $0.5 \mu \mathrm{m}, \mathbf{B}: 0.2 \mu \mathrm{m}, \mathbf{C}: 200 \mathrm{~nm}$.

smooth and with two strata: the inner stratum is strongly adhered to the exospore and more contrasted than the outer one. P2 layer is 0.2-0.6 $\mu \mathrm{m}$ thick and is constituted by radially arranged elements. Among those elements, contrasted areas alternate with lesser contrasted ones. P3 layer has a variable thickness of 0.2-1.1 $\mu \mathrm{m}$ depending on the area analyzed and it has higher 

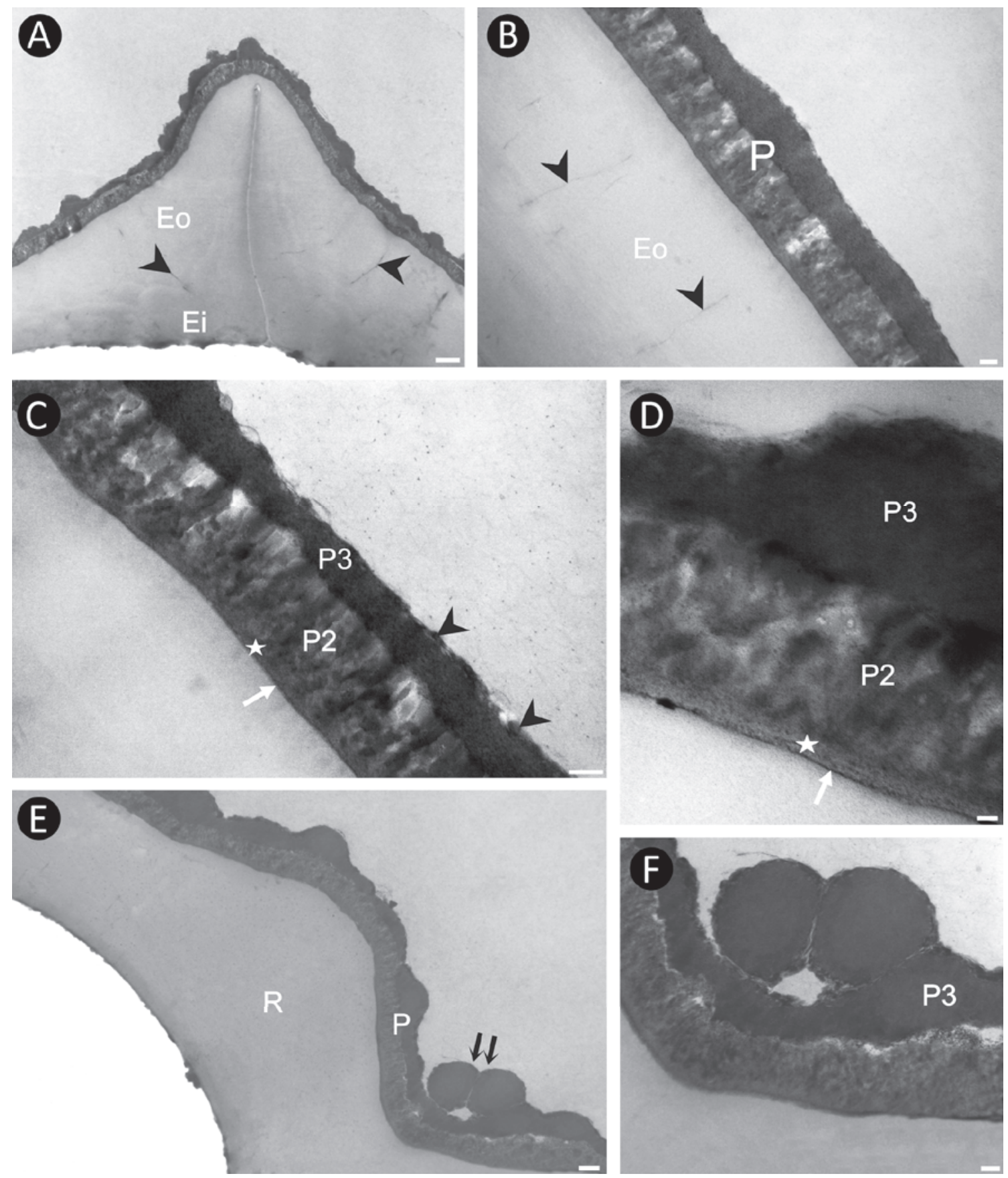

Fig. 5 - Spores of Lygodium volubile with TEM.

A. Section through the laesura. The inner exospore layer (Ei) shows higher contrast than the outer exospore (Eo). Some channels with dark content are visible on both sides of the laesura (arrowheads). B. The radial channels are observed in the outer exospore (Eo). Above the exospore, the perispore (P) is evident. C-D. The perispore is four-layered. The inner layer has two strata (arrow and star) which are smooth and strongly adhered to the exospore. P2 layer is composed of radially arranged elements. P3 layer forms the elements of the ornamentation. The outer layer, P4 (arrowhead), covers the outer surface of P3 layer. E. Section through the distal face of the spore. A ridge (R) of the exospore is observed. On the perispore (P) two spheroids are evident (double arrow). F. Detail of the spheroids. They have a similar structure and contrast to the perispore P3 layer. Scale bars: A: $1 \mu \mathrm{m}, \mathbf{B}: 0.2 \mu \mathrm{m}, \mathbf{C}: 200 \mathrm{~nm}, \mathbf{D}: 50 \mathrm{~nm}, \mathbf{E}: 0.5 \mu \mathrm{m}, \mathbf{F}: 0.2 \mu \mathrm{m}$. 
contrast than the other layers. This one forms the verrucae and tubercles of the spore surface. The outer layer, $\mathrm{P} 4$, is 40-55 $\mathrm{nm}$ thick and covers the outer surface of P3 layer.

Spheroids of 1.2-1.3 $\mu \mathrm{m}$, similar in structure and contrast to P3 layer are seen on the spore surface (Fig. 5 F).

\section{DISCUSSION AND CONCLUSION}

According to the results obtained in this work, and based on the information provided by LM or SEM, it can be concluded that the two species are differentiated by their spores. Lygodium venustum spores are verrucate-tuberculate in proximal and distal faces, and although $L$. volubile spores are also verrucate-tuberculate in the proximal face, they differ from L. venustum spores in a way that their distal face presents a few ridges oriented in several directions. The $L$. volubile spores also have an equatorial ridge that delimits facets proximally.

The results obtained in the present analysis for L. volubile share similarities with those by Tryon and Lugardon (1991), in which they defined the spores as having a verrucate distal face with an equatorial ridge, a two-layered exospore and a three-layered perispore.

As can be clearly seen in the ultrastructural analysis of the sporoderm, a two-layered exospore is present in both Lygodium species. However, the exospore of $L$. venustum has no ornamentation whereas in the case of $L$. volubile, the exospore has a wavy margin due to the ridges in section that appear in the distal face. These characteristics of the Lygodium spores allow for these species to be differentiated even when the perispore is not present.

The perispore is similar in both species; they share a four-layered perispore with a smooth basal layer, a complex layer with radially arranged elements and a thicker layer that forms the verrucae and tubercles.
However, there is a slight difference in the P2 layer of the perispore of the two species analyzed. In L. venustum, the layer seems to be more regularly organized, with more radially elongated elements than in L. volubile.

It is worth mentioning that the $\mathrm{P} 3$ perispore layer is the one which has the most significant variations in thickness in the different regions of the spores analyzed. In some cases, a region can be up to three times thicker in the area where the verrucae and tubercles are formed.

Based on the information provided here it is made apparent that in $L$. venustum, the perispore is the wall that forms the ornamentation of the spore while in the case of L. volubile, the perispore forms the ornamentation of the proximal face, and the exospore and perispore jointly contribute to form the spore ornamentation of the distal face.

In the present work, we defined P2 perispore layer as constituted by radially arranged elements. The elements were observed with contrasted areas alternating with lesser contrasted ones. Likewise, Tryon and Lugardon (1991) mention that the most contrasted zones of the elements of P2 perispore layer could be the silica found by Erdtman (1938) in the perispore of L. japonicum spores.

Besides, the P4 layer observed in the spores of L. volubile and particularly in L. venustum, was also cited by Tryon and Lugardon (1991) for L. japonicum. The authors mentioned that the additional laminae on the surface of the spores may be residual sporangial material.

Spheroids were seen on the spore surface of both species. A few of them were observed in $L$. venustum, and they were abundant especially in the distal face of the spores of $L$. volubile. Tryon and Tryon (1982) mentioned that the spherical depositions are characteristic of the spores of Lygodium that grow in America.

According to the ultrastructure presented here of these spheroids, they could be interpreted as spherules. As defined by Tryon and Lugardon 
(1991), in Schizaea Sm. and Salpichlaena J. Sm. the spherules are small bodies with a concentric arrangement of the different perisporal materials.

The comparative analysis of the two species of Lygodium studied in the current work may be useful in many respects: for clarifying the relationships among the taxa of the genus and for phylogenetic purposes.

\section{ACKNOWLEDGMENTS}

The authors thank Lic. Rafael Urrejola from the SEM Unit, Museo de Ciencias Naturales de La Plata and Lisandro Anton, from the TEM Unit, Instituto de Biología Celular, Facultad de Medicina, Universidad de Buenos Aires. This work was supported by grants from Universidad Nacional de La Plata (project 584) and Agencia Nacional de Promoción Científica y Tecnológica (ANPCyT) for project PICT 0661.

\section{RESUMO}

O gênero Lygodium Sw. é um das poucas samambaias trepadoras no mundo. Os esporos de $L$. venustum Sw. e L. volubile $\mathrm{Sw}$. foi estudados com microscopias de luz e eletrônicas de transmissão e varredura. Este trabalho é baseado em material de herbário. Os esporos são trilete, triangular com lados retos para convexo em vista polar. O equatorial diâmetro é 72-104 $\mu \mathrm{m}$ e o diâmetro polar é 64-84 $\mu \mathrm{m}$. O ornamentação em $L$. venustum é verrucosetuberculoso enquanto em $L$. volubile é verrucosetuberculoso no proximal cara e com poucos cume no distal cara, em que um micro-ornamentação constituída por verrugas e tubérculos é observado. Um cume equatorial também está presente. $\mathrm{O}$ exosporo é de dois camadas, em L. venustum é liso em contraste com o exosporo ornamentado de L. volubile. O perisporo é similar nas duas espécies analisadas. Esta parede é de quatro camadas com elementos particulares dispostas radialmente na camada do meio. Nas superfícies de esporos de ambas espécies poucos spheroids é observado. Os resultados apresentados no presente estudo podem ser útil para o sistemática do gênero bem como para propósitos filogeneticos.
Palavras-chave: Lygodiaceae, Lygodium, morfologia, esporos, ultraestrutura.

\section{REFERENCES}

De La Sota ER And Morbelli MA. 1987. Schizaeales. Phytomorphology 37: 365-393.

ERDTMAN G. 1938. Verkieselung und Verholzung der Sporen Membran bei Lygodium japonicum Sw. Svensk Bot Tidskr 26: 313-326.

ERDTMAN G. 1960. The acetolysis method. A revised description. Svensk Bot Tidskr 54: 561-564.

LUGARDON B. 1974. La estructure fine de l'exospore et de la perispore des Filicinées isosporées. II. Filicales. Commentaires. Pollen et Spores 16: 161-226.

Madeira PT, Pemberton RW AND Center TD. 2008. A molecular phylogeny of the genus Lygodium (Lygodiaceae) with special reference to the biological control and host range testing of Lygodium microphyllum. Biol Control 45: 308-318.

Mickel JT AND SMith AR. 2004. The Pteridophytes of Mexico. Mem New York Bot Gard 88: 48-60.

Morbelli MA. 1980. Morfología de las esporas de las Pteridophyta presentes en la Región Fuego-Patagónica. República Argentina. Opera Lilloana 28: 1-138.

ROWLEY JR AND NILSSON S. 1972. Structural stabilization for electron microscopy of pollen from herbarium specimens. Grana 12: 23-30.

Smith AR, Pryer KM, Schuettpelz E, Korall P, SCHNEIDER H AND WOLF PG. 2006. A classification for extant ferns. Taxon 55: 705-731.

TRYON AF AND LUGARDON B. 1991. Spores of Pteridophyta Springer-Verlag, New York, 648 p.

TRYON RM AND TRYON AF. 1982. Fern and allied plants with special reference to tropical America. Berlin, Heidelberg, Springer-Verlag, New York, 857 p.

VAN KONIJNENBURG-VAN CITTERT JHA. 1991. Diversification of spores in fossil and extant Schizaeaceae. In: BLACKMORE S AND BARNES SH (Eds), Pollen and Spores, Patterns of Diversification. Publ Syst Assoc, spec 44: 103-118. 